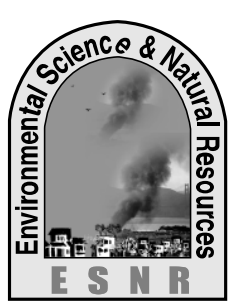

\title{
Studies on the Causes, Impacts and Mitigation Strategies of Landslide in Chittagong city, Bangladesh
}

\author{
M. T. Mia*, N. Sultana and A. Paul
}

Department of Geography and Environmental Studies, University of Chittagong, Chittagong-4331, Bangladesh

*Corresponding author: tanjil2009.bd@gmail.com

\begin{abstract}
Landslide is becoming a regular hazard in the urbanized hilly areas in Chittagong, Bangladesh. Generally, the hills consist of unconsolidated sedimentary rocks such as sandstone, siltstone, shale and conglomerate. Applying questionnaire survey with 120 respondents, and collection of secondary information, the study was carried out in two landslide prone sites located in Batali hill and Motijhrna area of Chittagong city for assessing the socio-economic condition of the people, causes of landslide, impacts of landslide on local people and mitigation strategies of landslide. People living in the study area were characterized by dominance of middle age group of population (52\%), illiterate (49\%), day laborer (27\%), migrated from the other places (93\%), low income (57\%) and having poor housing infrastructure. The present study indicates that landslide affect the poor people living on the slope of hilly areas. The main reasons identified for landslide were hill cutting (36\%), weak soil structure (23\%) and devegetation (16\%). The major impacts of landslide on the local communities, as reported by the respondents were loss of natural scenic beauty (77\%), economic loss (77\%), destruction of lives $(57 \%)$ and environmental problems (47\%). According to the respondents, the main mitigation strategies were stopping of hill cutting (75\%), resettlement of the affected people in other places (57\%), planting the affected area (55\%) and development of robust policy $(42 \%)$
\end{abstract}

Key words: Chittagong, Hill cutting, Landslide, Vulnerability

\section{Introduction}

Landslide is one of the most significant natural damaging disasters in hilly environments. In Bangladesh, the hilly areas are vulnerable to landslide as with the other hilly regions of the world. Landslide occurs every year in the hilly areas of Chittagong, a south-eastern part of Bangladesh (Ahmed et al., 2014). The hills generally consist of unconsolidated sedimentary rocks such as sandstone, siltstone, shale and conglomerate. Landslide is a term generally used to describe the downward movement of soil, rock and organic materials under the effects of gravity and also the landform that results from such movement (Highland and Bobrowsky, 2008). Rapid urbanization and human development activities such as, building and road construction through deforestation and excavation of hill slopes have increased landslide in densely populated cities located in mountainous areas (Galli and Guzzeti, 2007; Schuster and Highland, 2007).

Physiographically, most of the areas of Bangladesh is floodplain and only $18 \%$ is hilly and tract area (Islam and Uddin, 2002) where considerable proportion of people are living due to growing urbanization. Chittagong city has already been recognized as one of the most vulnerable cities to landslide. The city dwellers of Chittagong have experienced a number of devastating landslides. Different studies show that more than 500,000 impoverished people are living in informal settlements on the risky foothills of Chittagong city (Islam, 2008; Khan, 2008). Since 1997, landslides have caused the death of nearly 235 people in various informal settlements within Chittagong city and adjacent small urban centers (Technical Report, 2008). Chittagong hills are degrading by different anthropogenic stresses such as, hill cutting for construction, sand and clay mining, establishment of settlement in foothills, deforestation etc. Along with these, there are several other reasons responsible for creating vulnerability to landslide. Considering above facts, the present study was carried out to assess socioeconomic condition of the people living in the landslide prone area, causes of landslide, impacts of landslide on local communities and mitigation strategies of landslide to reduce vulnerability of landslide in the study area of Bangladesh.

\section{Materials and Methods}

\section{Location of the study area}

Chittagong city is situated within $22^{\circ} 14^{\prime}$ and $22^{\circ} 24{ }^{\prime} \mathrm{N}$ Latitude and between $91^{\circ} 46^{\prime}$ and $91^{\circ} 53^{\prime} \mathrm{E}$ Longitude and on the right bank of the river Karnaphuli. It is considered highly vulnerable areas where there are some human lives lost every year.

\section{Selection of the study area}

Landslide is a regular geologic hazard in Bangladesh, especially in Chittagong city. Especially, some areas of the city locally called Motijharna, Baizid Bostami, Kushumbag residential area, Batali Hill and Lebubagan are vulnerable to landslide. Among these areas, Batali hill and Motijharna are most densly populated and landslide prone area. For this reason, Batali hill and Motijharna have been selected for this study (Fig. 1).

\section{Data collection}

This research investigation was carried based on primary and secondary data during the period from January to April, 2012. For primary data collection, a semi-structured questionnaire was prepared. The questionnaire was developed on the basis of objectives to evaluate the landslide vulnerability and recommend for reducing the risk of landslide vulnerability in Chittagong city. After pilot survey, the questionnaire was then modified and rearranged according to the experience gathered. 


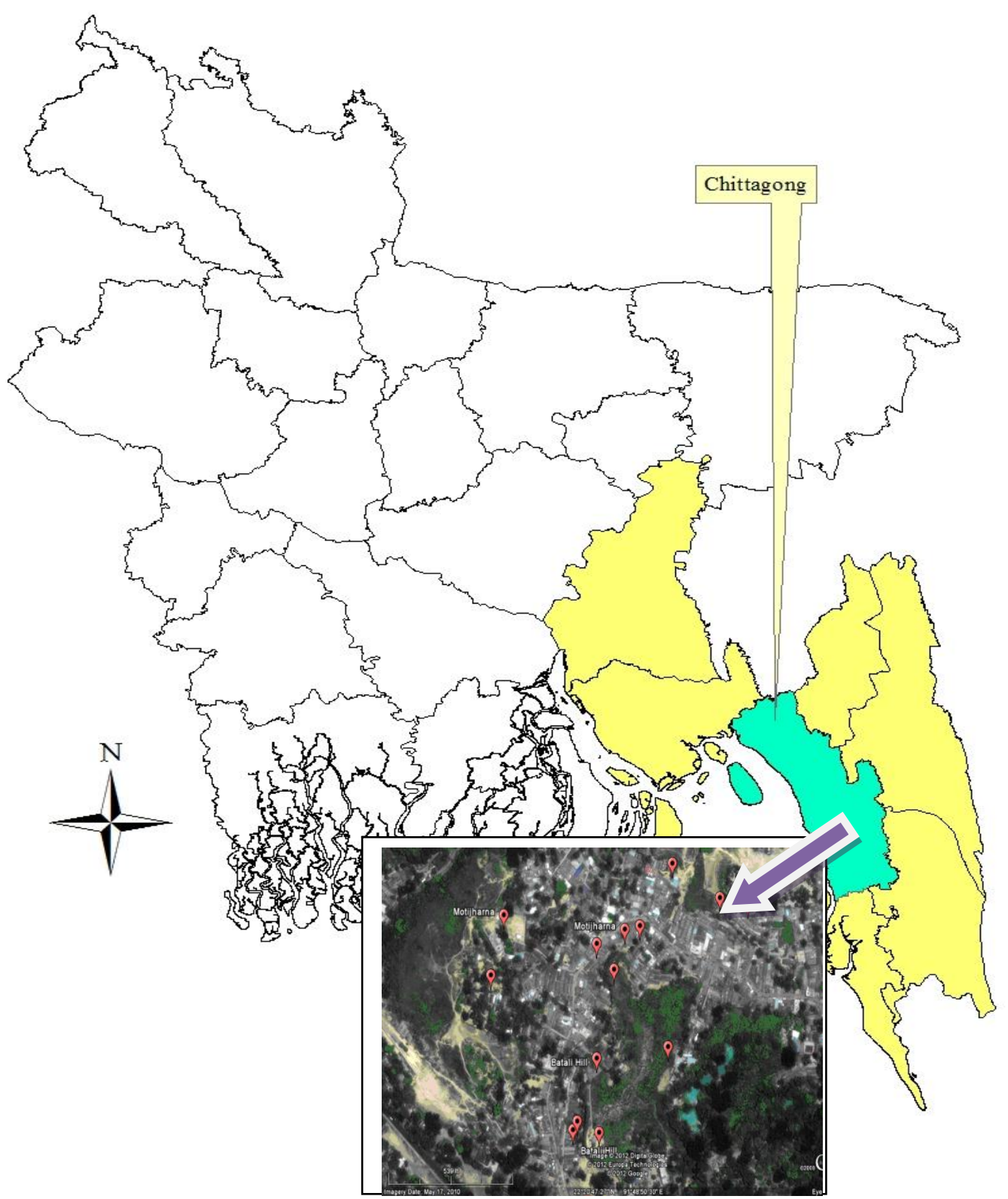

Fig. 1. Map of Bangladesh showing Chittagong district, with an embedded Google Earth image of the study area

The final questionnaire was then developed in a logical sequence so that the respondents could answer chronologically. A simple random sampling method was followed to find 60 respondents from Batali hill, and 60 from Motijharna area totaling 120 respondents. Both males and females working with various non-farm activities in the city were sampled for questionnaire survey. The respondents were interviewed in their houses, work places, shops and tea stalls. Moreover, relevant secondary information regarding landslide vulnerability in Chittagong city has been gathered from local authority particularly from the Department of Disaster Management. A large number of papers, journals, books, magazines, newspaper, thesis and other recent publications were also reviewed.

\section{Data processing and analysis}

The collected quantitative data were checked and then entered into the spreadsheet in MS Excel. Using statistical software SPSS (Statistical Package for Social Science, version 16.0), descriptive statistics including mean, frequency and percentage were analyzed from the collected data according to the objectives. The results are presented mostly in tabular forms along with graphs.

\section{Results and Discussion}

Socio-economic condition of the respondents

Age of the respondents is a mentionable factor which contributed to the research purpose to a greater extent. About $30 \%$ of respondents were in the young age (1530 years) group. However, the majority $(52 \%)$ of the respondents were of middle age group (31-45 years) indicating large number of non-farm workers living in landslide vulnerable areas (Table 1). Education is an important factor in changing the attitudes and motivation of the human being. Literacy status plays a vital role in an efficient participation and operational skill in all income generating activities. In the present study, the highest number of the respondents (49\%) was illiterate. About $27 \%$ of the respondents had primary 
level, and $20 \%$ had secondary level of education attainment (Table 1).

Table 1. Socio-economic status of the respondents in the study area

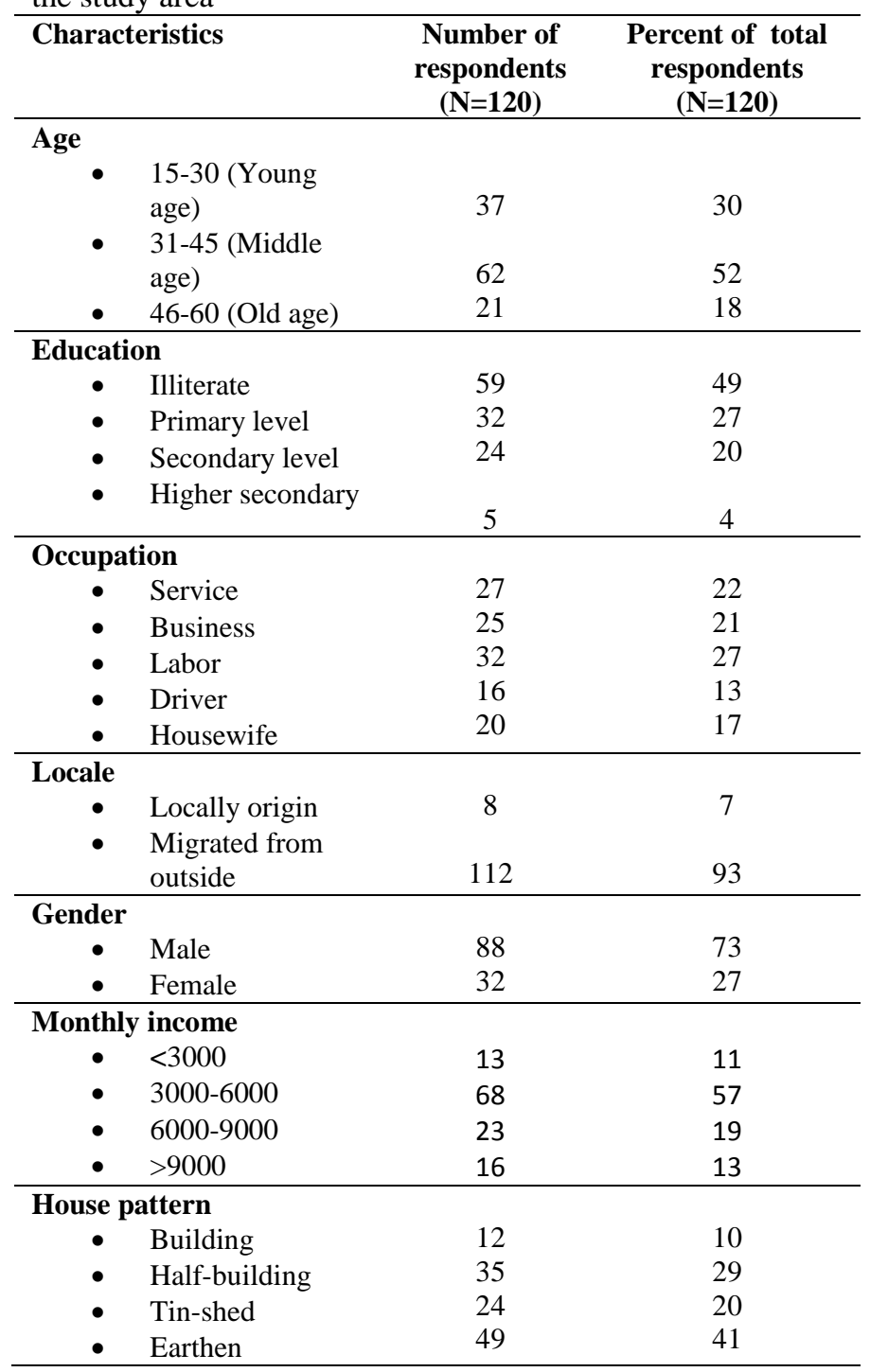

The income level of respondents were not sufficient for survive in the study. According to the survey, it was found that a considerable proportion of respondents $(27 \%)$ engaged in day laborer activities. About $21 \%$ were engaged with business, $22 \%$ service, $13 \%$ CNG driver and $17 \%$ housewife in the study area.

In the present study, about $7 \%$ of respondents were found permanent settler, and the remaining $(93 \%)$ was migratory who came from different distant places (Table 1). According to Ahmed et al. (2014), the people from the surrounding regions are migrating into the city areas for better income opportunities as well as attractive urban facilities because Chittagong is the port city and the commercial capital of the country. As a result, unplanned and haphazard urban growth of slum areas is taking place at different location of the city which creates environmental hazards and vulnerability to the landslide. In the present study, it was observed that majority $(73 \%)$ of the respondents was male. The monthly income of individual respondent ranged in various scales however, majority $(57 \%)$ of them earned BDT. 3000 - 6000 (US\$ 38.5 - 76.9) per month. This indicates that the hilly areas in Chittagong are mainly the residences of the lower income people and most of them were migrated from different regions of Bangladesh (Ahmed et al., 2014). Through the survey, it was found that maximum $(41 \%)$ house was earthen. About $10 \%$ was building, 29\% half-building and $20 \%$ tin-shed.

\section{Causes of landslide in the study area}

Landslide are considered as the most destructive hazards in developing countries, particularly where urbanization and population growth is high, and intensive land use and deforestation or mining practices are going on (Ahmed et al., 2014). There were many causes of landslide in Chittagong city reported by the respondents such as hill cutting, weak soil structure, devegetation, house construction and steeper hill, of which the major causes were hill cutting, weak soil structure and devegetation.

\section{Hill cutting}

Most of the landslide occurred in Chittagong region due to indiscriminate hill cutting. About $36 \%$ respondents reported that the major cause of landslide occurred due to hill cutting (Fig. 2).

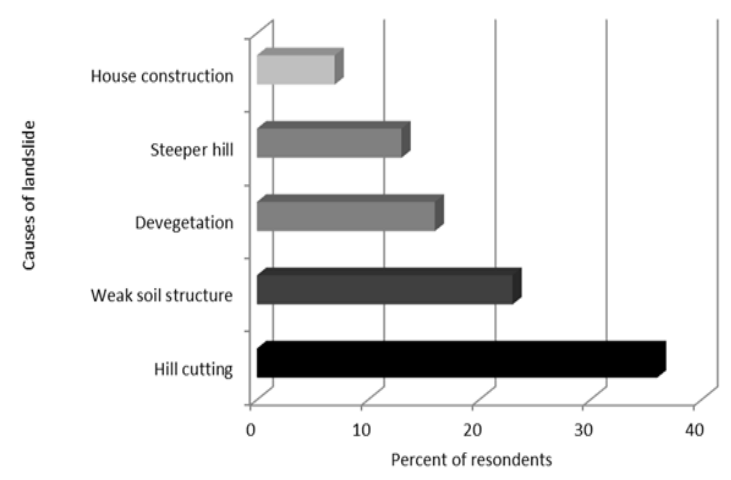

Fig. 2. Causes of landslide in the study area as perceived by the respondents $(\mathrm{N}=120)$.

According to Chisty (2014), hill cutting is one of the major causes of landslide in Chittagong city. This is being done for construction of building, developing residential/housing area, clay and sand mining and developing road network. Poor people living in the houses on the hilly areas are highly vulnerable to landslide. The hills of Chittagong were cut with slopes of 70-80 degrees (Mahmood and Khan, 2008) that makes the slopes instable.

\section{Weak soil structure}

About $23 \%$ of the respondents reported that weak soil structure was responsible for landslide (Fig. 2). In the hill cutting areas, soil erosion occurs easily during the rainfall. In Chittagong city, maximum hills consist of sandy and muddy soil which is easily eroded when heavy rainfall occurs in hill cutting slope areas. Eroded soil easily fills up low land areas and it also creates drainage congestion. Water dissolves the minerals of the soil of the hills that loosen its compaction during raining. Soils of the hills also become heavy by absorbing rainwater. If rain intensity is too high, minerals of soil dissolve very quickly and the soil turns into mud and becomes very heavy. The steep slope of 
the hill cannot bear the mass weight of the wet soil or mud that results the landslide (Chisty, 2014). According to Islam (2008), soil structure is an important contributing factor to landslide in Chittagong city. The soils of the city are sandy which makes them easily saturated during heavy rainfall and susceptible to massive soil erosion through formation of unstable and steep hill slopes (Khan, 2008).

\section{Devegetation}

In the present study about $16 \%$ of the respondents reported that devegetation in the hill was an important cause of landslide (Fig. 2). The vegetation covered areas are less vulnerable to landslide than deforested area (Sarwar, 2008). Root of the plants increase the compactness of the soil of hill. When this plant is destroyed by human activities than the soil compactness is gradually loosing. Rainfall easily flow the uncovered vegetation areas and increase the incident of landslide. However, large trees provide strong root structures into the earth that anchor the soil and protect it from erosion (Rahman, 2012).

\section{Impacts of landslide on the people's lives in the study area}

Landslide is occurring frequently in the hilly regions of the country (Alam et al., 2005) especially in Chittagong. Landslide has huge impacts on the human being and their environment, including effects on people, their homes and possessions, farms and livestock, industrial establishments and other structures. According to the survey, the major impact was related to destruction of human life, economic loss, environmental problem and loss of natural scenic beauty.

Impact of landslide on natural scenic beauty

Table 2. Major impacts of landslide on people's lives in the study area

\begin{tabular}{lcc}
\hline \multicolumn{1}{c}{ Problems } & $\begin{array}{c}\text { Number of } \\
\text { respondents } \\
(\mathbf{N = 1 2 0})\end{array}$ & $\begin{array}{l}\text { Percent of total } \\
\text { respondents } \\
(\mathbf{N = 1 2 0})\end{array}$ \\
\hline $\begin{array}{l}\text { Loss of natural } \\
\text { scenic beauty }\end{array}$ & 92 & 77 \\
$\begin{array}{l}\text { Economical loss } \\
\text { Destruction of } \\
\text { human life }\end{array}$ & 92 & 77 \\
$\begin{array}{l}\text { Environmental } \\
\text { problem }\end{array}$ & 68 & 57 \\
\hline
\end{tabular}

However, due to several human interventions, the natural scenery is declining day by day. For landslide, there are many changes of natural scenic beauty occurred. The maximum respondents $(77 \%)$ reported that the natural scenic beauty destroyed due to landslide in the study sites (Table 2).

\section{Impact of landslide on economy}

There was a considerable impact of landslide on the local economy. Due to the landslide, destructions of infrastructure, the household utilities, materials required for daily life are occurred. About $92 \%$ of the respondents faced economical problem after landslide in the study area (Table 2).

\section{Impact of landslide on human life}

There are many impacts of landslide on human lives. According to the survey, about $57 \%$ of respondents reported that human life was destroying due to landslide every year (Table 2). Among the landslide accidents, two tragic cases happened in Chittagong on 11 June 2007 and on 26 June 2012. On the first date in 2007, 127 people died in different locations of the city. On 2012, another landslide and mudflow after a heavy rainfall in Chittagong city occurred and left 26 dead bodies (The Daily Star, 2012).

\section{Environmental problem due to landslide}

Different kind of environmental problems were created due to landslide such as block of drainage connection, loss of soil fertility and loss of biodiversity of floral and faunal species and other resources. About $57 \%$ of the respondents opined that landslide created various environmental problems (Table 2).

\section{Mitigation the vulnerability of landslide}

It is clear that landslide causes death of large number of people every year which need sustainable mitigation. Mitigation is the use of strategies to reduce risks prior to, during and post- disaster, which is related to shortterm and long-term measures (Gabhok, 2004).

Table 3. Mitigation strategies of the vulnerability of landslide in the study area

\begin{tabular}{lcc}
\hline Characteristics & $\begin{array}{c}\text { Number of } \\
\text { respondents } \\
(\mathbf{N = 1 2 0})\end{array}$ & $\begin{array}{c}\text { Percent of total } \\
\text { respondents } \\
(\mathbf{N = 1 2 0})\end{array}$ \\
\hline $\begin{array}{l}\text { Stop hill cutting } \\
\begin{array}{l}\text { Resettlement of } \\
\text { house after landslide }\end{array}\end{array}$ & 90 & 75 \\
$\begin{array}{l}\text { Tree plantation and } \\
\text { vegetation }\end{array}$ & 68 & 57 \\
$\begin{array}{l}\text { Development of } \\
\text { policy }\end{array}$ & 66 & 55 \\
\hline
\end{tabular}

\section{Stop hill cutting}

According to the survey, about $75 \%$ of the respondents reported that stopping hill cutting is the main mitigating tool for reducing landslide occurrence (Table 3). To protect landslide, it is necessary to stop all types of hill cutting, sand collection and other activities which all cause landslide in Chittagong city (Sultana, 2013).

\section{Resettlement after landslide}

According to the study, it was known that after landslide occurrence, resettlement of the affected people in the safety places does not happen. This is due to some social and political factors in which hindrance of influential persons and landholder is the main factor. About $57 \%$ of the respondents considered resettlement of house of the affected people following landslide as an important mitigation strategy (Table 3).

\section{Tree plantation and vegetation}

About $55 \%$ of the respondents said that tree plantation and vegetation can mitigate the landslide (Table 3 ). The degree of land covered has a great effect on landslide as infiltration is a function of soil type and land use type. Hill soil directly exposed to rain has high filtration rate because of low surface run off. Exposed soil gets saturated by water earlier than the soil covered with plants. Also roots of trees reinforced soil increasing shear strength. Therefore, vegetation and planting more trees in landslide prone hills is the sustainable solution (Rubel and Ahmed, 2013). 


\section{Development of policy}

About $42 \%$ respondents reported that strong policy should be developed for mitigating landslide (Table 3). According to Sultana (2013), a comprehensive policy related to hill cutting, land use, hill use etc. needs to be formulated. Policy is the starting point for risk reduction activities. It sets ideas and concepts into motion and outlines the course of action to be taken.

\section{Conclusions}

Landslide vulnerability is an important issue for people living in the hilly areas of Chittagong city. In the recent years, landslide is occurring regularly. In the study area, vulnerability of landslide is mentionable than other landslide vulnerable areas in Chittagong city. The present study indicates that landslide affects the poor people living on the slope of hilly areas. The main reasons identified for landslide were hill cutting, weak soil structure and devegetation. The major impacts of landslide on the local communities were destruction of natural scenic beauty, economic loss, destruction of lives and environmental problems. The main mitigation strategies suggested by the respondents were stopping of hill cutting, resettlement of the affected people, vegetation and development of robust policy.

\section{References}

Ahmed, B.; Rahman, M. S.; Rahman, S.; Huq, F. F. and Ara, S. 2014. Landslide Inventory Report of Chittagong Metropolitan Area, Bangladesh. BUETJapan Institute of Disaster Prevention and Urban Safety (BUET-JIDPUS); Bangladesh University of Engineering and Technology (BUET), Dhaka-1000, Bangladesh. 125p.

Alam, E. M.; Chowdhury, M. A. T. and Akbar, M. T. 2005. Aspects of social environmental problems resulting from hill cutting in the city of Chittagong, Bangladesh: local people's perspectives. Pakistan Journal of Social Sciences, 3 (8):1048-1052.

Chisty, K. U. 2014. Bangladesh Institute of Planners Landslide in Chittagong City: A Perspective on Hill Cutting. Journal of Bangladesh Institute of Planners, 7: 1-17.

Gabhok, T. K. 2004. Disaster Management, The Commonwealth of Learning, Bangladesh Open University.

Galli, M. and Guzzetti, F. 2007. Landslide vulnerability criteria: A case study from Umbria, central Italy. Environmental management, 40: 649-664.
Highland, L. M. and Bobrowsky, P. 2008. The Landslide Handbook- A Guide to Understanding Landslides (Vol. Circular 1325, pp. 129p.). Reston, Virginia: U.S. Geological Survey (USGS).

Isalm, M. S. 2008. Causes of landslides and mitigation, paper presented at the daily star Roundtable on Challenges of development: Hill cutting and landslide in Chittagong Bangladesh on 30 August 2008.

Islam, M. N. and Uddin, M. N. 2002. Country Paper on Hydrogeology Section in International Workshop on Arsenic Issue in Bangladesh, 14-16 January, 2002,

Khan, I. S. 2008. Hill cutting in Chittagong City Corporation area: its causes and the consequences. $\mathrm{PhD}$ Dissertation, Khulna University Khulna, Bangladesh.

Mahmood, A. B. and Khan, M. H. 2008. Landslide vulnerability of Bangladesh Hills and sustainable Management options: A case study of 2007 Landslide in Chittagong City. Proceedings: International Seminar on Management and Mitigation of Water induced Disasters. 21-22 April 2008, Kathmandu. pp. 112-123.

Rahman, T. 2012. Landslide risk reduction of the informal foothill settlements of Chittagong city through strategic design measure. MS Thesis, BRAC University, Dhaka, Bangladesh. 115p.

Rubel, Y. A and Ahmed, B. 2013. Understanding the issues involved in urban landslide vulnerability in Chittagong metropolitan area, Bangladesh. MyCOE/SERVIR Himalayas Fellowship Program. $126 \mathrm{p}$.

Sarwar, G. M. 2008. Landslide Tragedy of Bangladesh. Paper presented at the First World Landslide Forum, United Nations University (UNU), Tokyo, Japan.

Schuster, L. R. and Highland, L. M. 2007. Urban landslides: socioeconomic impacts and overview of mitigative strategies. Bulletin of Engineering Geology and the Environment, 66: 1-27.

Sultana, T. 2013. Landslide disaster in Bangladesh: A case study of Chittagong university campus. International Journal of Research in Applied, 1(6): $35-42$.

Technical Report, 2008. Identification of landslide causes and recommendation for risk reduction. Chittagong Divisional Office, Chittagong, Bangladesh.

The Daily Star, 2011. "Another Death total now 15 in Chittagong mudslides". 12 July: 11. 